Peran Kejut Listrik dan Temperatur Sebagai Elisitor - Fitria, dkk Jurnal Pangan dan Agroindustri Vol.6 No.4: 18-25, Oktober 2018

\title{
PERAN KEJUT LISTRIK DAN TEMPERATUR SEBAGAI ELISITOR DALAM MENINGKATKAN KANDUNGAN SENYAWA BIOAKTIF DAN AKTIVITAS ANTIOKSIDAN PADA KEDELAI (Glycine max) : KAJIAN PUSTAKA
}

\section{The Role of Electric Shock and Temperature as an Elicitors in Improving The Content of Bioactive Compound and Antioxidant Activity in Soybean (Glycine max) : Literature Review}

\author{
Megy Wida Fitria, Widya Dwi Rukmi Putri, Jaya Mahar Maligan* \\ Jurusan Teknologi Hasil Pertanian, FTP Universitas Brawijaya Malang \\ Jl. Veteran, Malang 65145 \\ *Penulis Korespondensi, Email: maharajay@gmail.com
}

\begin{abstract}
ABSTRAK
Indonesia memiliki hasil panen komoditas pertanian yang melimpah salah satunya adalah kedelai. Kedelai biasa digunakan dalam pembuatan makanan seperti tempe, tahu, kecap dan lain-lain. Pada proses pembuatan makanan tersebut kedelai mengalami proses pemanasan yang dapat mengurangi kandungan senyawa bioaktif pada kedelai. Suatu upaya yang dapat dilakukan untuk meningkatkan kandungan senyawa bioaktif pada kedelai yaitu dengan elisitasi. Elisitasi adalah suatu metode yang memberikan kondisi tidak nyaman pada tanaman menggunakan media atau senyawa (elisitor) sehingga dapat membentuk metabolit sekunder yang berfungsi sebagai media pertahanan. Elisitor dapat berupa biotik (mikroorganisme, jamur dan herbivora) dan abiotik (ion logam berat, angin dan sinar UV). Elisitasi dalam beberapa penelitian dapat menggunakan kejut listrik dan temperatur sehingga kombinasi kejut listrik dan suhu diharapkan dapat berpotensi dalam peningkatan pembentukan metabolit sekunder. Mekanisme yang terjadi yaitu pemberian cekaman (lingkungan yang ekstrem) oleh kedua faktor tersebut akan memicu pembentukan gen-gen dan hormon yang dapat memicu terbentuknya metabolit sekunder sebagai pertahanan diri.
\end{abstract}

Kata Kunci: Kedelai, Elisitasi, Kejut Listrik, Temperatur

\section{ABSTRACT}

Indonesia has abundant harvest commodity one of which is soybean. Soybean is usually to make a food such as tempeh, tofu, soy sauce and others. Food making process with soybean has a drying with thermal that can decrease bioactive compound in soybean. One of way that can be done by elicitation. Elicitation is a method that can give an uncomfortable condition for plant using a medium or compound (elicitor) so that it can form secondary metabolite which function as a medium of self-defense. Elicitor is divided into two namely biotic (microorganism, fungi and herbivore) and abiotic (heavy metal ions, wind and UV light). Elicitation in several studies can use electric shock and temperature so it is expected 
to have the potential to increase secondary metabolites. The mechanism that occurs is giving stress (extreme environment) by these two factors will trigger the formation of genes and hormones that can trigger the formation of secondary metabolites.

Keyword: Soybean, Elicitation, Electric shock, Temperature

\section{PENDAHULUAN}

Kedelai merupakan salah satu komoditas pertanian dengan jumlah panen ketiga setelah padi dan jagung. Kedelai memiliki berbagai macam kandungan senyawa bioaktif diantaranya isoflavon, total fenol dan senyawa flavonoid yang berfungsi sebagai antioksidan (Kim, 2006). Pada pembuatan makanan dengan bahan kedelai terdapt proses pemanasan yang dapat menurunkan senyawa bioaktif pada kedelai. Proses perebusan dapat menurunkan kandungan isoflavon pada kedelai sebesar $46 \%$ (Simmone, 2000), total fenol berkurang sebesar 19,4\% dan kapasaitas antioksidan sebesar 32,8 \% (Preti, 2007).

Elisitasi adalah metode yang digunakan untuk membuat suatu kondisi tidak nyaman pada tanaman menggunakan elisitor sehingga akan memicu tanaman untuk menghasilkan metabolit sekunder yang berfungsi sebagai pertahanan diri (Radman et al., 2003). Elisitor merupakan suatu media yang menyebabkan kondisi tanaman mengalami cekaman (Radman et al., 2003). Elisitor dibagi menjadi dua yaitu biotik yaitu mikroba patogen, jamur dan herbivora dan abiotik yaitu senyawa anorganik, sinar UV, suhu, ion logam berat (Namdeo, 2007). Salah satu metode elisitasi yang akan dilakukan yaitu menggunakan kejut listrik dengan kombinasi variasi suhu.

Kejut listrik merupakan suatu metode perlakuan pendahuluan secara non termal dengan pemberian listrik kepada bahan pada tegangan tertentu (Menesses, 2011). Pemberian kejut listrik diharapkan dapat memberikan kondisi yang mengancam kepada tanaman sehingga dapat membentuk metabolit sekunder. Penggunaan kejut listrik yang diberikan pada tegangan 1, 3 dan $5 \mathrm{kV}$ dapat meningkatkan aktivitas pada buah beri sebesar $30 \%$ (Bobinaite et al., 2015). Suhu merupakan salah satu elisitor abiotik yang dapat menyebabkan keadaan yang tidak nyaman pada tanaman. Pada proses perebusan sayur terung dan wortel kandungan total fenol menurun sekitar $12 \%$ sedangkan nilai aktivitas antioksidan mengalami kenaikan sekitar $20 \%$ (Aisyah, 2014).

\section{Kedelai}

Kedelai merupakan salah satu tanaman yang memiliki bentuk polong-polongan yang menjadi bahan dasar berbagai macam makanan di Asia seperti tempe, tahu, kecap, tauco dan menjadi salah satu sumber minyak (Joe, 2011). Kedelai merupakan salah satu sumber protein yang banyak di konsumsi (Atman, 2014). Selain sebagai sumber protein, kedelai memiliki kandungan senyawa bioaktif berupa total fenol, flavonoid dan senyawa bioaktif lainnya (Yusnawan, 2016).

Penggunaan kedelai pada penelitian ini yaitu menggunakan kedelai jenis anjasmoro. Kedelai anjasmoro merupakan jenis kedelai yang banyak dimanfaatkan oleh masyarakat Indonesia untuk dijadikan bahan makanan seperti tahu dan tempe menurut penuturan dari 
staff Balitkabi. Kedelai ini memiiki benih yang besar, toleran terhadap penyakit dan pada setiap 100 biji mengandung protein sekitar 41,8 - 42,1 \% dan lemak sekitar 17,2 - 18,6 \% (Litbang, 2013).

\section{Elisitasi}

Elisitasi merupakan suatu metode yang diharapkan dapat meningkatkan produksi metabolit sekunder dengan cara pemberian elisitor biotik atau abiotik pada tumbuhan yang dapat mengakibatkan keadaan lingkungan yang lebih ekstrem dan mengaktifkan pertahanan tanaman untuk menghasilkan metabolit sekunder (Radman et al., 2003). Elisitor merupakan suatu media yang berfungsi dalam menciptakan suatu keadaan yang tidak nyaman pada tumbuhan sehingga dapat meningkatkan produksi metabolit sekunder pada tumbuhan (Angelova et al., 2006).

Elisitor dapat memicu dalam mengaktifkan sinal transduksi pada sistem sel karena dianggap sebagai molekul yang dapat mengakibatkan aktivasi dan ekspresi gen dalam pembentukan senyawa metabolit sekunder (Zhao et al., 2005). Elisitor dibedakan menjadi dua jenis yaitu elisitor biotik yang berupa makhluk hidup seperti jamur, mikroba patogen, herbivora dan elisitor abiotik yang berupa benda mati seperti ion logam berat, sinar UV, suhu dan sebagainya (Radman et al., 2003).

Penelitian tentang elisitasi telah dilakukan pada tanaman yang bertujuan untuk meningkatkan metabolit sekunder. Berdasarkan hasil penelitian Bou'e, (2008) menyatakan bahwa pelukaan pada ekstrak kedelai dapat mengakibatkan kenaikan aktivitas antioksidan, total fenolik dan flavonoid lebih tinggi daripada ekstrak kedelai yang tidak diberikan pelukaan. Berdasarkan penelitian Keng et al., (2010) penggunaan elisitor tertentu dapat mempengaruhi produksi alkaloid dan biomassa sel dari Eurycoma longifolia.

\section{Mekanisme Elisitasi}

Pembentukan metabolit sekunder oleh elisitor memiliki tahapan sseperti yang disajikan pada gambar (Gambar 1.). Elisitor yang berfungsi dalam memicu terbentuknya fitoaeksin akan membuat rangsangan terhadap reseptor yang terdapat pada permukaan sel yang akan menginduksi beberapa proses mekanisme pertahanan pada sel (Karla et al., 2016). Proses induksi yang terjadi antara lain pathogenesis-related (PR) proteins, aktivasi NADPH oksidase dan memproduksi Reactive Oxygen Species (ROS) dan Reactive Nitrogen Species (ROS), perubahan potensial reduksi pada sitoplasma dan peningkatan flux ion (pengeluaran $\mathrm{Cl}^{-} \mathrm{K}^{+}$ and pemasukan $\mathrm{Ca}^{2+}$ ),aktivasi gen-gen yang berhubungan dengan pertahanan, aktivasi mitogen-activated protein kinase (MAPK), pelepasan hormon jasmonate untuk menghasilkan metabolisme sekunder (Karla et al., 2016).

Metabolit sekunder akan terakumulasi dengan adanya produksi ROS dan RNS dari sel yang akan mengaktifasi MAPK dan hormon jasmonate sehingga memicu dan meregulasi faktor transkripsi gen didalam nukleus untuk mengekspresikan gen pembentuk metabolit sekunder (Baenas, 2014). Bahan yang digunakan dalam pembuatan metabolit sekunder berasal dari cadangan makanan pada kotiledon, seperti pati yang dirombak dahulu dengan enzim alfa-amilase dan beta-amilase menjadi glukosa (Yuliana A, 2003). Kemudian, ekspresi dari gen biosintesis untuk membentuk metabolit sekunder akan melepaskan hormon dan 
enzim-enzim yakan bekerja merombak glukosa menjadi metabolit sekunder.

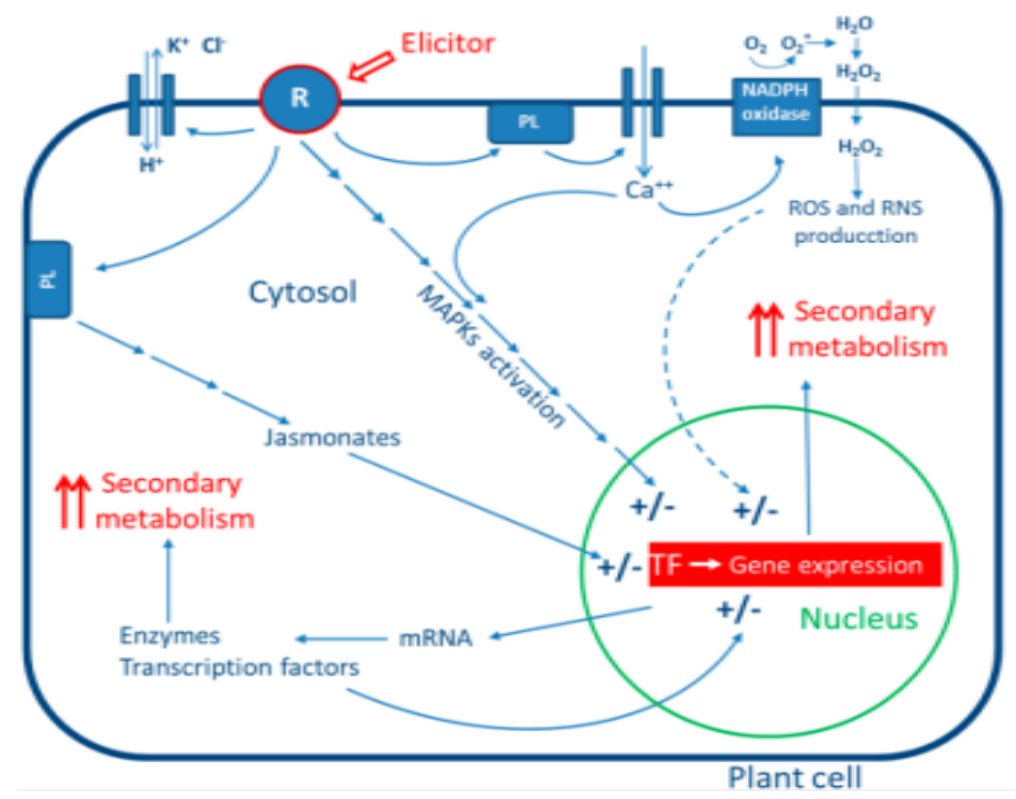

Gambar 1. Skema respon sel terhadap elisitasi (Karla et al., 2016)

\section{Kejut Listrik}

Kejut listrik atau yang biasa disebut Pulsed Electric Field (PEF) merupakan salah satu metode perlakuan pendahuluan bahan dengan menggunakan kejutan listrik dengan intensitas tinggi tanpa dipengaruhi oleh panas yang akan dihantarkan oleh pulsa denyut pendek tegangan tinggi ke bahan diantara dua elektroda (Canovas dan Howard, 2001). PEF yang diberikan kepada dapat mengganggu kinerja membran sel yang berfungsi dalam pengaturan segala aktivitas di dalam sel termasuk transportasi mekanisme. Pada suspensi sel padat dan dalam jaringan biologis yang kompleks akan terjadi fenomena permeabilisasi yang diinduksi PEF berdasarkan sistem model (vesikel fosfolipid dan bilayer planar) serta pada tingkat sel tunggal (Mikroorganisme), (Canovas dan Howard, 2001). Pengaruh kejut listrik yang diberikan t€

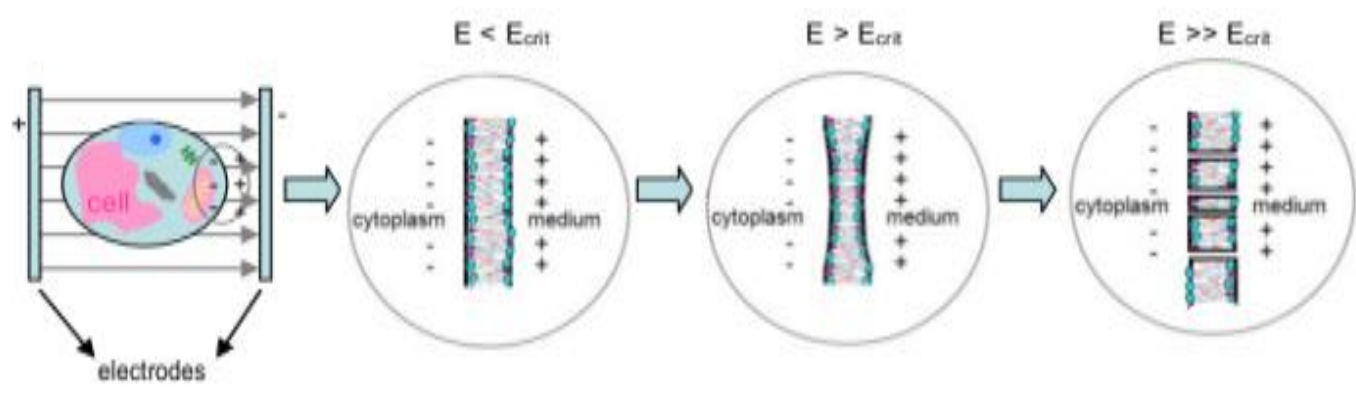

Gambar 2. Mekanisme PEF (Balasa,2012)

Pada saat tegangan diberikan muatan sel akan mengalami penarikan oleh kutub positif an negatif. Kerusakan pada sel akan terjadi apabila energi yang diberikan oleh PEF lebih besar daripada energi yang dapat ditahan oleh sel sehingga muatan sel akan tertarik dan menyebabkan pembentukan pori-pori pada membran sel, semakin besar energi yang 
diberikan maka pori-pori yang dihasilkan semakin besar dan menimbulkan kerusakan yang tidak dapat balik yang dapat menyebabkan isi sel keluar (Balasa, 2012).

\section{Aplikasi Kejut Listrik}

Kejut listrik memiliki berbagai macam aplikasi dalam dunia pangan. Berdasarkan permeabilisasi dari sel, kejut listrik dapat digunakan dalam berbagai macam aplikasi. Perbedaan permeabilitas pada tiap sel akan mempengaruhi besarnya tegangan yang digunakan (Vorobiev dan Lebovka, 2008). Aplikasi kejut listrik dapat digunakan untuk peningkatan nutrisi pada bahan pangan, ekstraksi dan keamanan pangan yang terdapat di dalam Tabel 1.

Tabel 1. Aplikasi Kejut Listrik

\begin{tabular}{|c|c|c|c|c|}
\hline $\begin{array}{c}\text { Intensitas } \\
\text { Pemrosesan }\end{array}$ & $\begin{array}{c}\text { Intensitas Kejut } \\
\text { Listrik (kV/cm) }\end{array}$ & $\begin{array}{c}\text { Durasi } \\
\text { Pulsa } \\
(\mu \mathrm{s})\end{array}$ & Permeabilitas Sel & Aplikasi \\
\hline Rendah & $0,1-1,5$ & $1-400$ & $\begin{array}{c}\text { Dapat balik } \\
\text { (reversible) }\end{array}$ & $\begin{array}{c}\text { Induksi sel dan } \\
\text { nilai nutrisi }\end{array}$ \\
\hline Sedang & $0,5-3$ & $1-400$ & $\begin{array}{c}\text { Tidak dapat kembali } \\
\text { (pada sel hewan } \\
\text { dan umbuhan) } \\
\text { (reversible) }\end{array}$ & $\begin{array}{c}\text { Pengeringan, } \\
\text { tekstur, } \\
\text { ekstraksi }\end{array}$ \\
\hline Tinggi & $15-40$ & $1-400$ & $\begin{array}{c}\text { Tidak dapat kembali } \\
\text { (pada sel } \\
\text { mikroorganisme) }\end{array}$ & $\begin{array}{c}\text { Keamanan } \\
\text { pangan }\end{array}$ \\
\hline
\end{tabular}

Pada bidang pangan, penelitian lebih ditekankan pada pengawetan pangan menggunakan kejut listrik yang dapat merusak sel mikroba dan tidak menggunakan panas sehingga tidak merusak nutrisi pada makanan (Toepfl, 2005). Peningkatan transfer biomassa (pengeringan, ekstraksi), aktivitas modifikasi untuk enzim dan sifat fungsional makanan disarankan menggunakan aplikasi kejut listrik dengan tegangan sedang (Lebovka et al., 2005). Selain itu, apikasi kejut lisrik dapat diterapkan pada permeabilisasi membran yang dapat balik (reversible) yang mempengaruhi sistem biologis pada sel dan menginduksi reaksi stres dan tetap mempertahankan viabilitas sel (Moritz, 2009).

\section{Pengaruh Suhu terhadap Senyawa Bioaktif}

Aktivitas antioksidan dapat dipengaruhi oleh beberapa faktor salah satunya adalah suhu. Kenaikan dan penurunan suhu yang terjadi dapat mengubah mekanisme tindakan dari antioksidan (Yanishlieva, 2001). Reaksi tertentu pada antioksidan dapat dipengaruhi oleh suhu (reaksi yang dipengaruhi oleh suhu terutama reaksi dengan radikal lipid dibandingkan reaksi samping, dimana senyawa yang diuji tidak bertindak sebagai antioksidan atau bertindak sebagai pro-oksidan) (Marinova dan Yanishlieva, 2003). Elisitasi menggunakan suhu $40^{\circ} \mathrm{C}$ pada kecambah kacang-kacangan dapat meningkatkan total fenol sebesar $18 \%$ dan asam askorbat sekitar $40 \%$ (Swieca, 2014). Pemilihan metode ekstraksi 
sangat penting dilakukan karena hasil ekstraksi akan mencerminkan tingkat keberhasilan metode tersebut. Aplikasi kejut listrik dan suhu pada proses elisitasi disajikan pada Tabel 2.

Tabel 2. Aplikasi Kejut Listrik dan Suhu pada Elisitasi

\begin{tabular}{|c|c|c|c|}
\hline No. & Judul & Perlakuan & Hasil \\
\hline 1 & $\begin{array}{l}\text { Pulsed Electric Field } \\
\text { Induced Stress in Plant } \\
\text { Systems (Balasa et al, } \\
\text { 2014) }\end{array}$ & $\begin{array}{l}\text { Penggunaan kejut listrik } \\
\text { pada apel dengan } \\
\text { tegangan output } 2,4 \mathrm{kV} \text {, } \\
5,6 \mathrm{kV}, 9,6 \mathrm{kV} \text { dan } 12 \mathrm{kV}\end{array}$ & $\begin{array}{l}\text { Pada tegangan output } 2,4 \mathrm{kV} \text {, } \\
5,6 \mathrm{kV} \text { dan } 9,6 \mathrm{kV} \text { sampel } \\
\text { mengalami kenaikan total } \\
\text { polifenol sedangkan pada } \\
\text { tegangan } 12 \mathrm{kV} \text { total polifenol } \\
\text { mengalami penurunan }\end{array}$ \\
\hline 2 & $\begin{array}{l}\text { Elicitation with Abiotic } \\
\text { Stresses improves Pro- } \\
\text { Health Constituents, } \\
\text { Antioxidant Potential } \\
\text { and Nutritional Quality } \\
\text { of Lentil Sprouts } \\
\text { (Swieca et al, 2014) }\end{array}$ & $\begin{array}{l}\text { Penggunaan suhu } 4^{\circ} \mathrm{C} \\
\text { dan } 40^{\circ} \mathrm{C} \text { selama } 1 \text { jam }\end{array}$ & 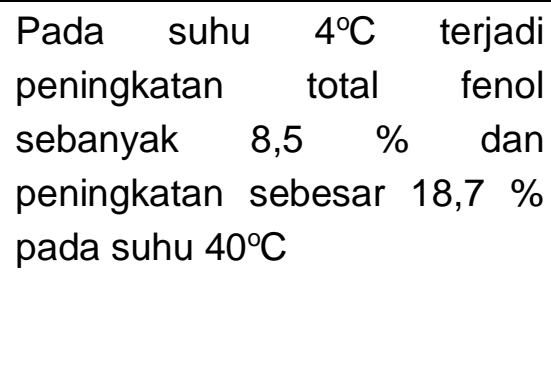 \\
\hline 3 & $\begin{array}{l}\text { Wound Induced } \\
\text { Changes in Phenolic } \\
\text { Metabolism and Tissue } \\
\text { Browning are } \\
\text { by Heat Shored } \\
\text { (Saltveit, 2000) }\end{array}$ & $\begin{array}{l}\text { Penggunaan suhu } 45^{\circ} \mathrm{C} \\
\text { selama } 90 \text { detik }\end{array}$ & $\begin{array}{l}\text { Penggunaan suhu } 45^{\circ} \mathrm{C} \\
\text { selama } 90 \text { detik dapat } \\
\text { meningkatkan kandungan total } \\
\text { fenol sekitar } 10 \%\end{array}$ \\
\hline
\end{tabular}

SIMPULAN

Elisitasi merupakan salah satu metode yang dapat digunakan untuk meningkatkan produksi metabolit sekunder pada tanaman. Metode ini merupakan salah satu solusi yang dapat digunakan dalam peningkatan senyawa bioaktif. Salah satu media yang digunakan dalam elisitasi menggunakan kondisi lingkungan yang ekstrem dan membuat tanaman menjadi tidak nyaman. Pada literatur ini diharapkan dapat menjadi acuan dalam penggunaan kombinasi kejut listrik dan suhu untuk proses elisitasi yang diharapkan penggunaan kedua faktor tersebut dapat meningkatkan kandungan senyawa bioaktif pada tanaman. Elisitasi dengan kombinasi kejut listrik dan suhu diharapkan berpotensi dapat meningkatkan pembentukan senyawa metabolit sekunder. Mekanisme yang terjadi yaitu pemberian kedua faktor (kejut listrik dan temperatur) menyebabkan kondisi lingkungan mencekam bagi sehingga dapat memicu terbentuknya gen-gen dan hormon yang berperan dalam pembentukan metabolit sekunder sebagai pertahanan diri. 


\section{DAFTAR PUSTAKA}

Aisyah. 2014. Pengaruh Pemanasan Terhadap Aktivitas Antioksidan pada Beberapa Jenis Sayuran. Jtipi. v6i2. 2063

Angelova, Z., S. Georgiev, and W. Roos. 2006. Elicitation of plants.Biotechnol. Eq. 20(2):72-83

Atman. 2014. Produksi Kedelai; Strategi Meningkatkan Produksi Kedelai Melalui PTT. Yogyakarta: Graha IImu.

Baenas et al., 2014. Elicitation: a tool for enriching the bioactive composition of foods. Molecules. 2014 Sep 1;19(9):13541-63

Balasa, et al., 2014. Pulsed Electric Field Induced Stress in Plant Systems. Berlin: Technischen Universitat Berlin

Bobinaite et.al. 2015. Application of pulsed electric field in the production of juice and extraction of bioactive compounds from blueberry fruits and their by-products. $J$ Food Sci Technol. Sep; 52(9): 5898-5905

Canovas, G. and H. Zhang. 2001. PEF in food processing. Lancaster

Joe, Wulan. 2011. 101 Plus Plus Khasiat Kedelai. Yogyakarta: Andi Publisher. Kementrian Pertanian: Jakarta

Karla, RE et al. 2016. Elicitation, an Effective Strategy for the Biotechnological Production of Bioactive High-Added Value Compounds in Plant Cell Factories. Molecul, 182

Keng, C.L., W.A. Sze, and B. Arvind. 2010. Elicitation effect on cell biomass and production of alkaloids in cell suspension culture of the topical tree Eurycoma longifolia. Journal of the Costa Rican Distance Education University 2(2):239-244

Kim E.H., Kim S.H., Chung J.I., Chi H.Y., Kim J.A., Chung I.M. 2006. Analysis of phenolic compounds and isoflavones in soybean seeds [Glycine max (L) Merill] and sprouts grown under different conditions. Eur. Food Res. Technol., 222, 201-208

Lebovka, et al. 2005. Temperature enhanced electroporation under the pulsed electric treatment of food tissue. Journal of Food Engineering, 69(2), 177-184

Litbang. 2013. Diakses dari http://en.litbang.pertanian.go.id/news/one/287/ pada tanggal 24 Mei 2018. Departemen Penelitian dan Pengembangan

Marinova, E.M. and Yanishlieva, N.V. 2003. Antioxidant Activity and Mechanism of Action of Some Phenolic Acids at Ambient and High Temperatures. Food Chemistry, 81, 189 197. http://dx.doi.org/10.1016/S0308-8146(02)00411-9

Menesess, N., Jaeger, H., Knorr, D. 2011. pH-changes during pulsed electric field treatments-Numerical simulation and in situ impact on polyphenoloxidase inactivation. Innov. Food Sci. Emerg. Technol. , 12 , 499-504

Moritz, J. 2008. Differentiation of process parameters during PEF treatment tegarding enzyme activity. Diplomarbeit thesis, Berlin, Technische Universität

Namdeo, A.G. 2007. Review article: plant cell elicitation for production of secondary metabolites. Pharmacognosy Reviews 1(1):69-79.

Preti, Raffaella. 2017. Effect of Steaming and Boiling on the Antioxidant Properties and Biogenic Amines Content in Green Bean (Phaseolus vulgaris) Varieties of Different Colours. Rome: Sapienza University of Rome 
Radman, R., T. Saez, C. Bucke, and T. Keshavarz. 2003. Elicitation of plant and microbial systems. Biotechnol. Appl. Biochem. 37:91-102

Simonne, A. H., Smith, M., Weaver, D. B., Vail, T., Barnes, S., \& Wei, C. I. (2000). Retention and changes of soy isoflavones and carotenoids in immature soybean seeds (Edamame) during processing. Journal of Agricultural and Food Chemistry, 48, 6061-6069

Swieca et al. 2014. Antioxidant Potentialof Fresh and Stord Lentil Sprouts Affected by Elicitation with Temperature Stresses. International of Food Science and Technology Vol. 49:, Issue, 8

Toepfl et al. 2005. Overview of Pulsed Electric Field Processing for Food. In D.-W. Sun. Emerging Technologies for Food Processing (pp. 69-97). Elsevier, Oxford

Vorobiev, E. and Lebovka, N. 2008. Pulsed-electric-fields-induced effects in plant tissues: fundamental aspects and perspectives of applications. In E. Vorobiev \& N. Lebovka. Electrotechnologies for extraction from food plants and biomaterials (pp. 39-81). Springer, New York

Yanishlieva N.V. (2001): Inhibiting oxidation. In: Pokorny J., Yanishlieva N.V., Gordon H. (eds): Antioxidants in Food - Practical Applications. Woodhead Publishing, Cambridge: 22-70

Yuliana, Anna. 2003. Pengaruh Penambahan Polisakarida Sebagai Elisitor Untuk Produksi Antioksidan Selama Selama Germinasi Biji Kacang Tunggak (Vigna unguiculata) dan Kedelai Hitam (Glycine max). Skripsi Fakultas Teknologi Pertanian IPB: Bogor

Yusnawan, E. 2016. The diversity of secondary metabolites in Indonesian soybean genotypes. Malang: Balitkabi

Zhao,W. 2007. Combined Effects of Heat and PEF on Microbial Inactivation and Quality of Liquid Egg Whites. International Journal of Food Engineering3(4) · January 2007 